\title{
哬D

\section{Innovative Education in Agroecology: Experiential Learning for a Sustainable Agriculture}

\author{
C.A. Francis \\ University of Nebraska-Lincoln
}

N. Jordan

University of Minnesota - Twin Cities

P. Porter

University of Minnesota - Twin Cities

T.A. Breland

Norwegian University of Life Science

G. Lieblein

Norwegian University of Life Science

See next page for additional authors

Follow this and additional works at: https://digitalcollections.dordt.edu/faculty_work

Part of the Agricultural and Resource Economics Commons, and the Educational Methods Commons

\section{Recommended Citation}

Francis, C.A, N Jordan, P Porter, T.A Breland, G Lieblein, L Salomonsson, N Sriskandarajah, M Wiedenhoeft, R DeHaan, I Braden, and V Langer. "Innovative Education in Agroecology: Experiential Learning for a Sustainable Agriculture." Critical Reviews in Plant Sciences. 30 (2011): 226-237.

This Article is brought to you for free and open access by Dordt Digital Collections. It has been accepted for inclusion in Faculty Work Comprehensive List by an authorized administrator of Dordt Digital Collections. For more information, please contact ingrid.mulder@dordt.edu. 


\title{
Innovative Education in Agroecology: Experiential Learning for a Sustainable Agriculture
}

\begin{abstract}
The transdisciplinary field of agroecology provides a platform for experiential learning based on an expanded vision of research on sustainable farming and food systems and the application of results in creating effective learning landscapes for students. With increased recognition of limitations of fossil fuels, fresh water, and available farmland, educators are changing focus from strategies to reach maximum yields to those that feature resource use efficiency and resilience of production systems in a less benign climate. To help students deal with complexity and uncertainty and a wide range of biological and social dimensions of the food challenge, a whole-systems approach that involves life-cycle analysis and consideration of long-term impacts of systems is essential. Seven educational case studies in the Nordic Region and the U.S. Midwest demonstrate how educators can incorporate theory of the ecology of food systems with the action learning component needed to develop student potentials to create responsible change in society. New roles of agroecology instructors and students are described as they pursue a co-learning strategy to develop and apply technology to assure the productivity and security of future food systems
\end{abstract}

\section{Keywords}

action education, service learning, transdisciplinary education, systems education, holistic learning, integrated systems

\section{Disciplines}

Agricultural and Resource Economics | Educational Methods

\section{Comments}

Copyright (C) Taylor \& Francis Group, LLC ISSN: 0735-2689 print / 1549-7836 online DOI: 10.1080/ 07352689.2011 .554497

This article may not exactly replicate the final version published in the journal. It is not the copy of record. See http://www.tandfonline.com/doi/abs/10.1080/07352689.2011.554497

\section{Authors}

C.A. Francis, N. Jordan, P. Porter, T.A. Breland, G. Lieblein, L. Salomonsson, N. Sriskandarajah, M. Wiedenhoeft, Robert DeHaan, I. Braden, and V. Langer 
Innovative Education in Agroecology: Experiential Learning for a Sustainable Agriculture by C. A. Francis, N. Jordan, P. Porter, T. A. Breland, G. Lieblein, L. Salomonsson, N. Sriskandarajah, M. Wiedenhoeft, R. DeHaan, I. Braden, V. Langer

Critical Reviews in Plant Sciences

Volume 30, Issue 1-2, 2011

Special Issue: Towards a More Sustainable Agriculture

\section{ABSTRACT}

The transdisciplinary field of agroecology provides a platform for experiential learning based on an expanded vision of research on sustainable farming and food systems and the application of results in creating effective learning landscapes for students. With increased recognition of limitations of fossil fuels, fresh water, and available farmland, educators are changing focus from strategies to reach maximum yields to those that feature resource use efficiency and resilience of production systems in a less benign climate. To help students deal with complexity and uncertainty and a wide range of biological and social dimensions of the food challenge, a whole-systems approach that involves life-cycle analysis and consideration of long-term impacts of systems is essential. Seven educational case studies in the Nordic Region and the U.S. Midwest demonstrate how educators can incorporate theory of the ecology of food systems with the action learning component needed to develop student potentials to create responsible change in society. New roles of agroecology instructors and students are described as they pursue a co-learning strategy to develop and apply technology to assure the productivity and security of future food systems.

\section{INTRODUCTION TO SYSTEMS AND EXPERIENTIAL LEARNING}

As global competition for land, water, and fossil fuels intensifies due to growing human population, we are facing unprecedented challenges in designing both research strategies and educational programs to help future professionals prepare to serve society. We applaud the impacts of the Green Revolution on yields of predominant cereal crops, and the effects of that research on alleviating hunger in many countries. Yet it is becoming increasingly apparent that other socio-economic and environmental factors must also be considered if we are to chart an effective course for the future. Based on over a decade of farming systems research and teaching practical field courses at universities in the United States and the Nordic Region, we are convinced that the transdisciplinary field of agroecology offers great promise to: 1) expand the vision in research on sustainable agricultural systems, and through this research, 2) inform the design of effective learning landscapes for students who want to make an impact on future food and farming systems. The central goal is to develop competencies of students in agroecology.

Agroecology research and teaching emerges from a focus on sustainable agriculture, gathering increased momentum as more people recognize the limits of fossil fuels, fresh water, and available farmland. Most scientists agree that global climate change will impact production, and that much of our current productivity and the resulting growth in human numbers have been due to development of a technology appropriate to cheap fossil fuels, available water, and relatively benign climates that have characterized the past two centuries (Kirschenmann, 2009). With looming constraints to productivity due to limited resources and an imperative to feed a growing human population, agricultural and food systems scientists are looking at larger systems issues as well as alternative research methods and strategies that will contribute to solutions in the context of resource scarcity. Likewise, students will be faced with challenges full of uncertainty and increased complexity, needing a multi-perspective approach to seek solutions.

Sustainable agriculture provided an umbrella for valuable research and education for the past two decades. Although the term is ambiguous - no one would claim to be designing a non-sustainable system-it is a useful concept and statement of purpose, if not a precise goal nor menu for specific farming systems or practices. The term has been overused and adopted by groups across the spectrum of political persuasion and environmental perspective, from Greenpeace to Monsanto. This has added to confusion and caused loss of credibility. Some universities have chosen to focus on the study of agroecology, a term broadly defined as the ecology of food systems (Francis et al., 2003), and a rigorous academic area closely linked to practice and meaningful action. We adopt this definition for 
education in agroecology, while recognizing that the term has been used more narrowly to explain agriculture in ecological terms (Altieri, 1983; Gliessman, 1984).

Richard Bawden's article on systems thinking and research is frequently cited by agricultural educators as a key reference point for application of systems principles in the educational arena (Bawden, 1991). His pioneering experiential learning program at University of Western Sidney in Hawkesbury, with students working with farmers and ranchers near the university, provided incentive to implement on-farm education components in programs in other countries. The concept of double loop learning and building on experience was summarized by Sriskandarajah et al. (1990) in the context of farming systems research and extension. Wilson and Morren (1990) provided synthesis of methods around systems research, in a text frequently used in teaching integrated systems theory and practice. These resources bring a logical combination of theory and application to put the principles of systems analysis to practical use. We build on the strategy for competence development (Bawden, 2007a).

The systems approach in agriculture is a multi-perspective way of seeing the world, distinct from that employed by single disciplines. Holistic thinking requires a systemic approach to observing and analyzing complex situations in agriculture and food systems. While research on individual components of the system is often essential, this work is most valuable when conducted with an appreciation of the whole system in mind. When looking at the likely impacts of a new high-yielding wheat variety, for example, it is important to consider the prices and long-term availability of needed inputs, the impacts on the local and regional environment, and the social consequences of introducing this variety, such as farm size, concentration of markets, and distribution of benefits. These are factors not often considered by the plant breeder who is closely focused on the goal of increasing genetic production potential. Agroecology provides a framework within which to study the multiple consequences of new technology introduction.

Another unique characteristic of agroecology as applied in research programs in the United States and Norway is the blending of biophysical and social science methods, the latter sometimes called soft systems methods (Checkland, 1981; Checkland and Scholes, 2001). Employing such methods as surveys, interviews, focus groups, and personal observations of people and groups, these research and learning strategies are appropriate to evaluate many aspects of human activity systems, including those that involve farming and food. This window on the human component of systems complements the observations and measurements of crop and animal enterprises, analysis of short-term economics, and evaluation of environmental impacts on farm and in the landscape. When combined with biological methods, this strategy provides multiple windows on the systems of interest, and allows us to approach situations that are filled with multiple interacting dimensions and uncertainty with some confidence of understanding complexity. This wide range of methods has been employed in a diverse array of MSc thesis projects: waste water for vegetable production in Havana, composting organic waste in Yaounde, food policy councils in Canada, and growth of organic farming in Colombia. In Norway, the thesis projects have included meat goat production in the mountains, agrotourism in the north, farmers markets across the country, and farmers as teachers on the west coast. This combined strategy to research can open vistas to innovative perspectives on food and farming systems challenges that would not be possible with single discipline research and education methods.

An important academic foundation for experiential learning was provided by the legendary John Dewey (1916), who maintained that all learning must be put into context of prior knowledge and experience, and that the key was "learning by doing." His theories were employed widely in agriculture for half a century, as colleges featured farm practice experiences that were tied closely to academic topics in the classroom. Field experience requirements were abandoned along with two-year practical degrees in most U.S. landgrant universities. Study of agriculture evolved into genetics, entomology, engineering, pathology, and economics as individual disciplines, organized into departments and majors. Breadth requirements assured that students were exposed to other disciplines, but most topics were taught as stand-alone courses rather than as components of complex systems. Many of the practical advantages of general agriculture education and appreciation of systems complexity eroded in favor of biotechnology, macroeconomics, and environmental science, each studied as independent and self-contained disciplines with their own language and culture.

Courses in sustainable agriculture, organic farming, and integrated agricultural development gained a dedicated following in some universities in the 1990s. These were organized and driven by a few faculty members, often champions of the cause who had prior Peace Corps or other experience in developing countries. They were motivated in part by the educational liberation philosophy of Paulo Freire (1970) who viewed teachers and students 
as learning together and focusing primarily on outcomes of education such as development for the masses and distribution of benefits of farming and food systems.

Challenges of teaching sustainable agriculture and agroecology in landgrant universities have been explored (Altieri and Francis, 1992). There are defined courses needed for an undergraduate degree in agriculture, and many instructors maintain that credits taken in integrative systems take away opportunities for more in-depth preparation in specific disciplines such as agronomy, entomology, plant pathology, economics, or engineering. Innovative educators and curriculum planners now accept the value of systems thinking as provided in these integrative courses, and more offerings are appearing in public and private universities (Francis, 2009). A systems approach to study across disciplines will provide students with important competencies they will need to deal with complexity and uncertainty in the future.

\section{TRANSDISCIPLINARY EDUCATION IN AN ECO-SOCIAL SYSTEM}

Conventional wisdom in the U.S. landgrant system maintains that both research and teaching are enhanced by a close link between them. The strategy of split appointments, with researchers actively working on contemporary issues and bringing the latest results to the classroom, has pervaded our thinking. Linking research with teaching and learning can be valued in undergraduate courses on sustainability if the research is continually viewed in the context of whole systems; the link could be detrimental to learning if the successful researcher in component science has difficulty emerging from that specialty to provide a systems perspective on applications to critical issues. In the landgrant system, split appointments can present an acute problem if major rewards are based on research publications and grant success. One review concludes that most research evidence does not find a positive correlation between success in research and success in teaching (e.g., Hattie and Marsh, 1996; 2002; Jenkins et al., 2003). Organization of most universities includes separate budgets, assignments, and facilities for the two activities, even though faculty have split appointments (Barnett, 2005). Lieblein et al. (2000b) provide three models of university structure, including a conventional model and two futuristic alternatives that depend on teams doing experiential learning on farms and in communities.

A workshop of the European Network of Organic Agriculture Teachers (ENOAT) in Italy explored the challenges and potentials of the interaction of teaching and research in agroecology and organic farming (Caporali et al., 2007). There was strong agreement about the importance of working across disciplinary lines as the only rational way to deal with broad and complex issues. We recognized multidisciplinary as an approach that brings together multiple disciplines, but does not guarantee an integration of perspectives or research methods, nor any emergent value of the process. There is not necessarily an equal sharing of the parts (Schunn et al., 1998). Interdisciplinary strategies are important to address problems that "escape the confines of a single discipline" (Mittelstrass, 1998), yet leave the impression that they deal primarily with the issues that would otherwise fall through the cracks between specialties. Transdisciplinary is a term of choice because it concerns "that which is at once between the disciplines, across the different disciplines, and beyond all disciplines. Its goal is the understanding of the present world, of which one of the imperatives is the unity of knowledge" (Basarab, 2002).

Competency in agroecology requires skills that go beyond what is available in any one department or specialization. Challenges in agricultural and food systems involve use of natural resources, complicated farming practices, economics in a time of uncertainty, environmental impacts, and social implications of decisions in these human activity systems. Lieblein and Francis (2007a) provide a review of literature on linkages between research and teaching, ways to bridge what is often envisioned as a gap, and a proposed "learning umbrella" that covers both activities (Brew and Boud, 1995). The cases we present later describe relevant examples of research-based educational activities that contribute to systems competencies.

\section{AGROECOLOGY AS A FOUNDATION FOR SUSTAINABLE AGRICULTURE}

\section{A. Emergence of an Integrative Ecology of Food Systems: Agroecology}

Societal demands on agriculture are mounting and becoming more complex. In addition to major increases in global food production in coming decades, society increasingly expects rural landscapes to provide a wide range of other goods, services and amenities. These include biofuels, bio-industrial products (Eaglesham, 2006) and environmental services such as carbon storage, biodiversity conservation, aquifer recharge (Boody et al., 2005; Jordan et al., 2007), 
and the construction of resilient land-use systems to manage risks from climate change (Berkes, 2007). The challenge is to increase production of marketable commodities, while maintaining integrity of essential life-support functions of the biosphere. More broadly, the challenge is to better design and manage the interconnections between agriculture and basic life-support systems of society: food, water, energy and land-use systems. Such demands must be met within the context of global environmental change, especially greater climate instability. The intertwined issues of production, conservation and adaptation constitute one of our grand challenges facing humanity. It will be necessary to substantially redesign agricultural systems and their interface with food, water, energy and land-use systems (Francis and Porter, 2010).

Any redesign will be complex and contested, involving difficulties aptly described as 'wicked' problems (Batie, 2008). In these situations, different parties view and define the problem quite differently, depending on their particular worldviews, values, and vested interests. Wicked problems typically entail high levels of uncertainty and large 'decision stakes' (i.e., large public risks and/or opportunities are involved). They are marked by strong controversy, stakes are high, the facts of the situation are uncertain, and intense debate occurs among stakeholders holding wide-ranging views on what constitutes sustainable and responsible development in social, economic, and environmental terms (Jordan et al., 2008). Wicked problems in agriculture are also biocomplex, meaning that production, conservation and adaptation are affected by the interplay of biophysical and social factors that are spatially, organizationally and historically complex (Cottingham, 2002; Pickett et al., 2005).

How should society organize itself in response to wicked problems in agriculture and interconnected food, energy, water and land-use systems? Sustainability science (Clark, 2006) is providing a rallying point for many efforts to answer this question. This field views the interplay of social and biophysical factors as the genesis of wicked problems. To make progress, sustainability science aims to create new understanding by close coupling of multiple knowledge systems into 'learning systems' based on social networks (Ison et al., 2007). Making durable improvements in the face of wicked problems requires multiple rationalities, including intellectual, practical, spiritual, emotional, ethical, and aesthetic. To meet these needs, natural and social scientists must engage with broader knowledge systems and learning/action networks, by involving heterogeneous groups of stakeholders. When learning and action are effectively integrated, stakeholder groups can take concerted and coordinated action (Magerum, 2002; Pahl-Wostl and Hare, 2004; Steyaert et al., 2007; Mandarano, 2008) that can contribute to progress in the face of wicked problems in managed ecosystems.

Motivated by hope of better addressing wicked problems and by emerging tenets of sustainability science, the discipline of agroecology has recently shifted strongly toward a more integrative mode (Flora, 2001; Uphoff, 2002; Dalgaard et al., 2003; Francis et al., 2003; Jordan et al., 2005a; 2008; Robertson et al., 2008; Warner, 2008; Francis et al., 2008). Wezel et al. (2009) found that contemporary usage of 'agroecology' reveals a range of non-exclusive meanings, variously describing a science, a practice, and/or a popular movement as applied in Germany, France, Brazil, the United States and elsewhere. Agroecology initially was used to describe and analyze production-related issues in farming systems via natural science, combining the perspectives of agronomy and agriculture with ecology. This conception of agroecology-as-science persists today in a number of countries including France and the United States.

\section{B. Broadening Agroecology to Include Food Systems}

The concept of agroecology has been broadened substantially to include environmental, economic, social, political, and ethical dimensions. Academics in the Nordic Region and the U.S. Midwest now define agroecology as the ecology of food systems (Francis et al., 2003). This definition may need additional revision to reflect societal demands that agriculture produce a range of non-food goods, services and amenities. Wezel et al. (2009) contend that a more expansive use of the term emerged in the 1970s with agroecology seen as both a set of practical applications and a movement. This activity was partly in response to the concerns about unexpected consequences of the highly successful Green Revolution in developing countries, such as environmental impacts of substantial increases in chemical fertilizer and pesticide use, and high-tech/high-yield strategies that often ignored social structure and distribution of benefits.

Agroecology has potential to embrace a broad, complex, interacting set of biophysical and socioeconomic dimensions of food systems. Beyond opening unique vistas for research, there is an exciting array of applications in experiential learning as illustrated by the case studies described later. Integrative qualities emerge that can enhance 
the value of research and education. For example, there is focus on long-term, place-based, comparative research and development projects (Carpenter et al., 2009) using tools such as foodshed analysis (Peters et al., 2009) and life cycle analysis (Hendrickson et al., 2006), and such ecological concepts as hierarchy of scale, system boundaries, and evaluation of biodiversity and nutrient cycles. There is also potential for integration of multiple natural and socialscientific methods such as multi-scale empirical work, modeling, simulation and adaptive experimentation (Cook et al., 2004), and analyses that integrate patterns and processes across a wide range of spatiotemporal scales such as competition and mutualism, biogeochemical cycles, and biological and social succession.

These same concepts and principles can inform the design of 'learning landscapes' in which students are introduced to the complexities and uncertainty of farming and food systems in the present and their design for the future. We have found that students who study to become agroecologists through applied systems courses in the Nordic Region gain an appreciation of how to deal with complicated and multi-dimensional situations (Lieblein et al., 2004). In design of educational strategies, we have focused on the learner, on sharing responsibility for education, and on students taking an active role in a process that can lead to capacity for responsible action (Lieblein and Francis, 2007b). It is the evolution of agroecology from a singular focus on science, to an incorporation of practical applications, to creation of movements in several countries that has enriched this area of study. To pursue a broad strategy of experiential learning in agriculture and food systems, we have found a need for different types of activities, including modifications in practical learning through case studies.

\section{Open-Ended Case Studies: A Primary Learning Strategy}

One key method for education in agroecology that has proven valuable for systems learning is the open-ended case study (Francis et al., 2009). One prerequisite for learning is to generate enthusiasm around a topic and another to create linkages to prior experience (Dewey, 1916). The decision case method has been used by many educators to meet these needs, but the majority of such cases are "closed" in that they present situations in which the solution is already known to instructor and client (American Society of Agronomy, 2006). The open-ended cases we use in agroecology are distinct in their process of joint exploration by students, instructors, and clients of complex real-life situations where often neither the relevant questions nor the answers have yet been identified (Francis et al., 2009). The open case method is further characterized by introducing students to a discovery approach to learning, to the need for digging out relevant information on a farm or in a community, to develop potential future scenarios rather than providing one discrete solution, and to elaborate a series of criteria for evaluating success of the scenarios.

Compared to conventional decision cases, the open-ended case study strategy places primary emphasis on colearning by students, instructors, and clients (Francis et al., 2009). The goal of seeking information in the field from farmer or community key clients is to develop a rich picture of the current situation, and to establish as much as possible the long-term goals of farmer or community and what they would like to achieve within a certain time frame. This depends on the natural resource and economic base, and also on individual and social capital in that place and the philosophies and world views of the participants. There is an open co-learning atmosphere where everyone is a player in defining the issues and seeking alternative solutions for the future. Multiple sources of information and stimulation feed into continuous interaction among the players. In Norway, student teams are working with farmers and communities that have a goal to increase organic food consumption. The projects are taking "action research" to a new level of accountability, yet there is a safe space under the learning umbrella to venture broadly and take risks that would not be encouraged in a conventional class setting.

\section{CASE STUDIES IN EXPERIENTIAL SYSTEMS LEARNING}

\section{A. Norway: UMB Agroecology Courses with Open-ended Cases}

For the past decade, the autumn courses at the Norwegian University of Life Sciences (UMB) have provided study opportunities in food and farming systems using the open-ended case strategy. Based on concepts developed in oneweek Ph.D. courses on systems research in the mid-1990s (Lieblein et al., 1999), the semester includes an experiential learning component on farms and in rural communities in Norway. Design of the initial courses was informed by an in-depth evaluation in a workshop of former faculty and student participants (Lieblein et al., 2000a).We have observed that the inclusiveness and transparency in planning and implementation of courses have been valuable as a way to involve people from the Nordic Region and to help in recruiting students. 
At the heart of the semester are open-ended case studies that explore contemporary challenges facing farmers and current issues in food systems in Norwegian communities. As we explain to students, the cases have not yet been solved. We work together as a team of students/faculty/clients to create a rich picture of the situation, the goals of farmer and community, and the resources available. Student teams identify the key issues, and then design a series of potential scenarios that could be used by farmer or community to address them (Francis et al., 2009). This is quite different from students doing a decision case where they must be clever enough to find out what the instructor and client already know. Based on field visits, observations, and interviews, students consider multiple ways of analyzing the current system and then design scenarios toward a desired future situation that will help clients meet their goals. Teams produce client documents for their key contacts in the field, and individual students prepare learning documents that summarize their personal experiences in learning. We now collaborate with a national program seeking to help Norway reach its stated goal of $15 \%$ organic food production and consumption by 2020 . The Økoløft program funds half the cost of team visits to communities, and this raises the level of responsibility and accountability for everyone in the project.

Scenario building and evaluation of impacts are representative of the steps up toward visioning and action that are encompassed in the external learning ladder conceptualized in this program (Lieblein et al., 2007). The open-ended case study strategy is integral to becoming an agroecologist and systems thinker, well prepared to deal with complexity and with rapidly changing situations (Lieblein et al., 2004). Agroecology courses prepare students to make meaningful contributions to the food system through responsible action in the future (Lieblein and Francis, 2007b). In a sense, students are working on real-world issues in real time, and are gathering information as it is needed in this "just-in-time" learning environment (Salomonsson et al., 2005).

\section{B. U.S.: Midwest Agroecosystems Analysis Course}

Since 1998, a summer experiential learning course to develop competencies in agroecosystems analysis has been held each year in Iowa, Minnesota, and Nebraska (Wiedenhoeft et al., 2003). The goals are to give students firsthand experience in the dominant maize-soybean and confined livestock plus alternative farming systems in the region, and to provide tools for collecting information, analyzing, and evaluating the sustainability of different farms. Students focus on production, economics, environmental impact, and social viability of each operation, and learn to use various biological and social science methods (Rickerl and Francis, 2004). Provided with references ahead of the field visits and practice with interview skills and farm models, students then are given broad leeway in how they organize their interviews, design analyses, and summarize results in oral and written presentations. The instructors consider this freedom to make decisions as one key to developing competence as autonomous learners.

The course begins on the southern edge of the Des Moines lobe formed during the latest glacial period, with discussions about glacial formation, movement, and recession. Consequences for the landscape and soils, and how the climax northern tall grass prairie impacts potential for agriculture are explored, as students walk through a field never plowed, one piece of the $0.01 \%$ of this Iowa ecosystem that remains (Samson and Knopf, 1994), Most people including those involved in agriculture do not recognize prairie. The current state of northern tallgrass prairie conservation is reviewed and participants are introduced to the most conspicuous prairie plants and encouraged to explore on their own and get a feel for the ecosystem. In a group discussion participants share what they have seen and felt, and consider how 'prairie wisdom' might be put to work in contemporary food production systems. The prairie ecosystem then is identified as one standard by which environmental sustainability and farming systems resilience in the region can be evaluated. One student said, "I think the prairie misses the bison."

The class visits eight farms, delving into farmers' philosophies and goals, natural resource and economic endowments, and current systems with their successes and challenges. Based on this experience and evaluation, they envision potential future scenarios. Students are urged to develop meaningful questions and envision alternative future directions that would better help each farmer achieve their goals. The emphasis is on system resilience and sustainability, on potential of the farmer and family to flourish even in times of uncertainty and economic change, and on dealing with complexity through application of ecological principles in design of farming systems. In the study of systems, students look at issues across hierarchies of scale and time. They explore the intricate interactions among components and the emergent properties of systems, and as much as possible attempt to take a holistic and systemic view of the overall operation of the farm within the landscape and local community context. The result has been a revelation to those students who are accustomed to learning in specific disciplines, at times with information 
that is context free, and who have been told specifically what they are supposed to learn. The open-ended case study approach has proven valuable for learning and building systems competencies.

Evaluation of learning in the agroecosystems analysis course has been multidimensional, using daily individual surveys of students and faculty, frequent reflection sessions, careful instructor reading of students' individual learner documents submitted at the end of the course, peer evaluations within groups, faculty observations of students in the field and in group work, and follow-through surveys and interviews after the course is finished. From these sources, Harms et al. (2009) have identified five causal conditions that are influential in creating learning and the conditions that would encourage behavioral change in students: hands-on experience, emotional response, human interaction, self-efficacy, and intensity of experience. They found additional conditions that need to be considered to improve the learning situation: length of course, appropriateness and rigor of curriculum, learner-centered activities, ongoing education, and metacognitive processes.

\section{U.S.: Integrative Agroecology}

Ecology of Agricultural Systems is a course at University of Minnesota-Twin Cities which prepares students to design and manage the interconnections between agriculture and basic life-support systems of society: food, water, energy, and land use. Design and management must interweave production, conservation and continuous adaptation to change at many scales, and presents practitioners with many 'wicked' problems (Batie, 2008), those in which different parties view and define problems quite differently. There may be strong controversy and biocomplexity, in which production, conservation and adaptation are affected by the interplay of biophysical and social factors that are spatially, organizationally and historically complex.

The premise of Ecology of Agricultural Systems is that difficult problems in agriculture must be addressed by a novel and emerging discipline, termed 'integrative agroecology,' itself a realization of a new 'meta-discipline' of sustainability science (Clark, 2006). Agriculture and related food, water, energy and land-use systems are understood as coupled human-natural systems (CHNS) (Liu et al., 2007). Such coupling creates potential for strong and rapid feedback dynamics, with coupled 'ecosocial' interactions in CHNS that are fundamental to integrative agroecology.

Ecology of Agricultural Systems was designed to provide useful concepts for viewing agriculture through the lens of integrative agroecology, use practical experiences, and encourage reflection on concepts and practice. Because integrative agroecology is new, we emphasize methods of agroecological analysis and the development of mental models and perspectives, such as an ability to perceive wicked problems in agriculture and their relationships with systems of food, energy, water and land-use. To do this, the course offers experience in applying methods for systems thinking to complex agricultural issues. We organize model-making and other activities to practice 'systemicity' around two focal notions. Landscapes are the land areas containing multiple ecosystems that are distinct in structure and function. Management regimes are the multiple agencies, organizations and institutions from different social sectors (technological, financial, commercial, regulatory, physical and biological infrastructure) that interact to govern resource and production systems. Students develop and evaluate their models and other course concepts in a semester-long project that features 'community-based learning' (CBL), also known as service learning (Jordan et al., 2005). They are engaged with partner organizations that provide a practical application for the work.

\section{Sweden: Swedish Test Pilots}

A unique experiment was launched at the Swedish University of Agricultural Sciences (SLU) in Uppsala where a number of crop science students were not satisfied with their current curriculum, immersed in chemistry and molecular biology, and were seeking more relevance in education. With an expectation to learn about agriculture as a human driven activity in its socio-economic and ecological context, students found that crop science courses did not provide this breadth of focus. Three students chose to plan their own systems studies, first in Sweden and later in Viet Nam. They embraced the concept of experiential learning and took on the responsibility for planning their own systems research and learning experiences. In the first eight weeks they made multiple farm visits and conducted indepth interviews of farmers on two farms, one conventional and one organic, in the fertile valley north of Uppsala. They explored the inputs and outputs from the farms; beyond the farm boundaries they looked at the complexity of 
the food system after harvest in the processing and marketing of products from the farms. An integrated report of the study was presented to their advisor and to the farmers.

Concerned that they were not stretching their comfort zones with this study in Sweden, the group decided to travel to Viet Nam to study farming systems and marketing at a local university and then conduct action research in the field. After substantial reading and preparation, they spent two weeks in seminar-type sessions on the campus of Hue University, in cooperation with a masters program project with SLU and Vietnamese universities [theRDViet Project, http://www.rdviet.net/] doing systems analysis study together with local college students. Supervised by teachers from An Giang University, they spent a week in field studies in two villages with rice production as the primary economic activity. One was an ethnic Vietnamese village and the other a Khmer village. To explore the impacts of globalization on the decisions of farmers in these two contrasting places, students conducted interviews with relatively wealthy farmers, average farmers, and poor farmers, as well as with a focus group of decision makers in each community. Through translators, they examined the impacts of recent growth of export markets for Viet Nam on the apparent financial success and well-being of these farmers and families. This was a tremendous experience for the students, and they prepared a report on the adventure that was published by their department at SLU (Palmer et al., 2008). In addition, the process of developing the concept and carrying out the research/ education project was summarized and published in an education journal with the students and instructors as coauthors (Salomonsson et al., 2008). This model is seen as a potential future type of class for highly motivated students who want to take responsibility for their own systems education, and to do this outside the intellectual and physical confines of the university classroom and department structure.

\section{E. U.S.: African Agroecology Systems Evaluation through Adventure Learning}

In spring semester 2009, students at University of Minnesota participated in an adventure learning course in agroecology where the instructor (Paul Porter) planned to travel over a four month period from Cairo, Egypt to Cape Town, South Africa by bicycle, reporting on the agroecosystems and food he encountered each day. Adventure learning $(\mathrm{AL})$ is a hybrid distance education approach that provides students with opportunities to explore real-world issues through authentic learning experiences within collaborative learning environments (Doering, 2006).

"Food and Agriculture from Cairo to Cape Town at $10 \mathrm{mph}$," provided students with an introduction to food, agriculture and agroecosystems in 10 African countries (Egypt, Sudan, Ethiopia, Kenya, Tanzania, Malawi, Zambia, Botswana, Namibia, and South Africa). The instructor traveled by bicycle over 6000 kilometers through five countries until a bicycling accident in southern Tanzania cut short his travel, but not the course. Students continued to follow the bicycling group until they arrived in Cape Town.

Co-taught by a teaching assistant, the course utilized faculty guest speakers, student group presentations and related readings from a wide array of disciplines, from climatology and culture to social and agronomic sciences. With satellite phone technology and the internet, the instructor provided daily written and audio-blogs of his experiences, focusing on food, agriculture, and agroecosystems. Each day he would travel about 120 kilometers, and report on the ecology of farming and food systems he encountered. Discussion ranged from topics on false banana, t'ef and cultivating with livestock on terraces to challenges of nomadic herdsmen and the constant quest for water. Relationships among climate, soil, elevation and latitude were discussed relative to historic and current cropping practices. Well over 100 plant and animal species were discussed, far more diverse than what typical U.S. students find in the Midwest.

There was no textbook for the course. Assigned readings included peer reviewed articles, current events, development reports and daily blogs posted by the instructor <http://paulporter.wordpress.com>. The course was offered as a general elective for undergraduates as well as to honors students and graduate students; 34 students from five colleges representing 13 majors enrolled in the three-credit course. In their course evaluations, the students expressed a sense of 'being there' and experiencing crossing deserts in the heat on rough roads, surviving thin air and seeing cool season crops at higher elevations, as well as the transition from barren dry environments to biologically diverse intercropped landscapes. Building from lessons learned, a similar course was conducted in 2010, when the instructor completed the agroecology journey through Africa. This creative type of educational experience enhances the breadth of learning opportunities to which the students are exposed and provides a model for developing new competencies through distance education. 


\section{F. U.S.: Learning Communities}

In higher education, curricular learning communities offer a common cohort of students the opportunity to build community while enrolled in classes that are linked or clustered during an academic term, often around an interdisciplinary theme. Recognizing that learning is a social endeavor, the goal of learning communities is to impact student learning by creating purposeful groupings of students. At Iowa State University this approach has been used to help students make the transition from high school to university, to increase retention of students, to encourage greater student engagement academically and socially, and to stimulate greater success in learning. The students take similar classes, as well as linked classes, i.e., English composition classes linked to discipline content classes (Wiedenhoeft and Loynachan, 2009). The community idea organizes students into groups to provide a smaller college atmosphere within the large landgrant university.

In 1998 and 1999, three groups of 12 first-year agronomy students were organized; two of the groups were in learning communities, while the third group was not (Pogranichniy et al., 2001). All three groups enrolled in the same required courses. The learning community groups were given an additional two-day field trip, as well as weekly special seminar sessions on time management, appreciation of different learning styles, study and testing skills, and opportunities for career exploration. There was greater faculty/staff involvement with the community groups, including peer mentors, faculty mentors and a staff coordinator. After two years of this experience, faculty reported that the program had "some limited success." Those students participating in the learning communities had a quicker adjustment from high school to the university learning environment, a small but significant increase in academic performance as measured by grade point average, and a slightly higher level of student retention. What was important to faculty involved in the communities was the qualitative observation that students were better adjusted to the university. This was enough to justify continuing the program, and today this is an integral option for undergraduate students at Iowa State University (Wiedenhoeft and Loynachan, 2009).

\section{G. Nordic Region: On-Line Course in Agroecology}

Since 2004 a fully web-based course in agroecology has been offered globally by instructors from four Nordic universities (Lieblein et al., 2005). To build competencies, the course offers an introduction to the systems approach and complements specific courses students have taken in other disciplines. Instructors introduce an experiential learning approach in which dialogue between the 'real world' and the 'abstract' (Kolb, 1984) can be used in a distance learning situation. Using Kolb's learning cycle with an example from the real world, we developed a case based on a Danish organic dairy farm. With quantitative farm data as well as qualitative information from interviews with the farmer and his family, the case is the focal point of student work through the course.

Course activities followed the Kolb's cycle, pulling in theoretical background and the tools needed along the way. An initial question is, What is on the farm and how does the farm function? Theory is introduced through readings on systems thinking and agroecology, as well as mind-mapping and other tools. Later questions focus on goal conflicts and the tasks of making sound recommendations to the farmer. This approach calls for students to put themselves into the roles of different players, including farmer and advisor. Students work both in groups and individually and keep learning logs through the course to ensure reflection on their own learning.

Instructors had a long history of collaboration in adopting student-centered and experiential approaches, yet the development and implementation of this distance course was a new learning experience for all. Teachers represent a wide range of disciplines within agriculture, food science, and veterinary medicine. Facilitating a learning process on the farming system level puts less emphasis on each specific field of expertise, thus instructors need the courage to move out of their comfort zones in dealing with students and the material, as well as opening the potential of an innovative learning approach.

Challenges that are addressed during the course relate to cultural and geographical differences among the students. Like most international groups, students enter the course not only with a diverse set of knowledge and experiences, but also with large differences in their attitudes toward learning, authorities, and group work. Since the course started we have revised the material annually, changing the readings, including emerging discussions on multifunctional agriculture, and changing some of the tools offered, such as SWOT and Force Field analysis. 
Taking into account the increasing student numbers from the South we plan to expand the applied component with a case from the developing world, giving students from all backgrounds the opportunity to work with different contexts and expand their agroecology competencies.

\section{FUTURE LEARNING LANDSCAPES: AGROECOLOGY AND EXPERIENTIAL EDUCATION}

Despite increasing calls for graduate training in integrative agroecology (Francis et al., 2008), efforts to develop more programs that draw on the conceptual developments outlined in the introduction have been limited. Some programs in sustainability science, land-change science, and new critical understanding of participatory approaches are being tested (Bawden, 2007b; Ison et al., 2007; Jordan et al., 2008). Excellent graduate programs address sustainable agriculture (e.g., Iowa State Univ. http://www.sust.ag.iastate.edu) but we are not aware of graduate programs that address the broader challenge of applying the emerging frameworks of biocomplexity, sustainability science, and land-change science to create an integrative agroecology framework. Relevant systems education programs are emerging in the Nordic region (e.g., Nordic School of Agroecology, www.agroasis.org). Useful insights come from frameworks created by graduate curricula in sustainability science in a range of physical sciences and ecological sciences (Francis et al., 2008). Recent start-up programs include the School of Sustainability at Arizona State University (http://schoolofsustainability.asu.edu) and the Resilience and Adaptation Program at University of Alaska (http://www.rap.uaf.edu).

A fundamental premise is that our students will be involved in the development of new systems of governance, or new management regimes to better manage interconnections between agriculture and overarching resource systems of food, energy, water and land-use. Network forms of governance can enable effective co-managementcoordinated, concerted and collective action across multiple social, economic, political sectors and scales. We view these network governance mechanisms as a necessary complement and counterweight to regulatory and market forces (Ison et al., 2007). To become effective agroecologists, our students must develop a set of perspectives, habits of minds and behavioral competencies that will enable them to participate in network governance and comanagement. Among these abilities, new capacities for communicative and systemic learning are particularly important. Crucial outcomes are well summarized in a rubric - the 'Five Cs' - recently articulated by Richard Bawden, a seminal figure in agroecology education (Bawden, 2007b; Jordan et al., 2008). The 'Five Cs' are both key attributes of the wicked problems that new management regimes must address and related competencies that must be developed to enable students to become agroecologists capable of facing wicked challenges. These attributes and related competencies are:

- Contestability, requiring competencies for engaging productively with differences in worldview, values, and interests among multiple stakeholders in wicked problems,

- Contingency, requiring competencies for dealing with unpredictable futures in agricultural systems beset by difficult problems rooted in biocomplexity,

- Collectivity, requiring competencies in social learning for collective action,

- Connectivity, requiring competencies in methods for systemic understanding,

- Cognition, mental models, habits of mind and worldviews are powerful factors in wicked problems, strongly affecting understanding and action of interested parties; agroecologists need competencies for critical understanding of cognition and learning - individual and collective - to deal with future complexity.

Communicative learning is applied in the Habermas/Mezirow sense (Mezirow, 1996) as a process that helps us understand how others see the world, in terms of theoretical validity, normative correctness and honesty of views. This learning increases understanding of the meaning and significance of statements and actions in a group of interacting stakeholders. The outcome is increased capacity for communication and deliberation, enabling increases in mutual understanding, collaborative learning, and collective action (Bawden, 2007a; Jordan et al., 2008). Such learning creates a critically important basis for co-management and increased social capital, including trust, willingness to cooperate, and shared norms and values. Systemic learning is also fundamental, because agriculture and related resource systems are seen as coupled human-natural systems, and to understand them requires students to learn and practice systems thinking. Systemic learning refers to understanding the holistic nature of agriculture, with all its complexities and interactions (Bawden, 2007b). Systemic learning involves inquiry and analysis on three 
interrelated levels: systems, sub-systems, and super-systems (Jordan et al., 2005). Finally, communicative and systemic learning can be integrated via the formation of 'critical learning systems' (CLS) (Bawden, 2005), which are comprised of social actors (individuals, organizations, institutions) that share a common interest in an agroecosystem. Ability to apply these concepts is an important competency for agroecologists.

Drawing on these new theories and experiences in the literature, we are building on the early concepts of Dewey (1916) and other visionaries, and we are applying the theory to courses in the Nordic Region and the U.S. Midwest to improve the learning landscape. Instructors in these courses understand the links that provide an efficient transfer of relevant experience and information from the research laboratory, experimental field, and rural community into the classroom. We recognize the value of student research and class projects as important sources of ideas that we can use to deal with contemporary challenges in farming and food systems. We believe that experiential learning is an effective means to achieve education for students concerned about responsible action, and these are the people who are going to make a difference in the world and the human condition. Our focus is on building competencies in agroecologists, by designing coherent curricula or learning landscapes that transcend the intrinsic limitations of individual courses that are often narrow learning experiences of limited scope and duration.

In such a learning landscape, we help students develop the competencies listed above to participate in CLS, and also the underlying capacities for communicative and systemic learning. For example, we believe that agricultural scientists concerned with such challenges need capacity for intellectually rigorous foresight (Tonn et al., 2000), using such techniques as scenario planning and facilitated modeling (Kallis et al., 2006). They also need holistic approaches suited to more immediate challenges, such as soft-systems methodology (Jordan et al., 2005), and social multi-criteria analysis or adaptive co-management (Olsson et al., 2007; Berkes, 2007) or skill in the creation and use of boundary objects (Steyaert, 2007) such as texts and graphics. These convey information about social or biophysical attributes of an agroecosystem and serve to facilitate critical systems thinking by a multi-stakeholder group, for example a terrainanalysis map depicting areas vulnerable to soil erosion. Established and emerging methods for communicative and systemic learning are the key features of agroecology curricula, leading to new ways of seeing and corresponding ways of doing.

From case studies, from experiences of the past decade, and from recent conceptual developments, we can draw out a number of key elements and conclusions:

- learning is a social as well as an individual process, and there is a continuing need to explore the best ways to enhance effective team project work,

- knowledge, skills, competencies, and attitudes must go beyond technical details; ability to work in groups, capacity to see the larger picture, experience in communication with the public, and broad capacity to deal with uncertainty, risk and change are essential,

- experiential learning means getting into the field and the community, working with clients to understand their goals and local context, and appreciating uniqueness of place and specificity of solutions to location specific individual and group challenges,

- methods of service- and community-based learning provide useful guidelines, in principle and practice, for such community-engaged learning,

- transdisciplinary team teaching is crucial to the broad goals of learning about systems; there are biophysical, economic, social and political dimensions in contemporary problems, important in developing resilient and sustainable alternatives,

- frequent and meaningful interactions among the instructors have been essential to applying broad concepts, guiding students through learning landscapes, and evaluation,

- bringing together natural resource and biodiversity questions with those in agricultural production, farm and regional economics, complex social realities, and political dimensions involve developing different types of practical models to help students understand complexity, and require methods from both biophysical and social sciences, 
- methods for integrative analyses are hardly well defined in the domain of agroecology research, and practical pedagogical models are very much a work-in-progress,

- evaluation is an integral and continuing part of design and implementation of experiential learning activities and programs, and frequent modification along the way through educational adaptive management has been important to success,

- recognizing the intensity of instructor involvement in this type of learning environment is important, as administrators and peer evaluators look at credit hour accumulation as the key indicator of educational "success" in today's tight economic times; we need to seek resource-efficient alternatives to achieve the same goals without excessive investment of faculty time and university resources.

Major areas for future development include the application of methods for systemic and communicative learning to agroecological curricula.. This is especially important for undergraduate curricula, as these students are conditioned to rote learning and may be at stages of cognitive development that create significant impediments to systemic and communicative learning (Salner, 1986). Techniques such as soft-systems methodology are considered to be difficult to teach to undergraduates. Also needed are opportunities for critical self-reflection, for example meta-cognition and epistemic cognition, particularly on the basis of experiences that engage students for reasonably long periods. These are opportunities to apply and evaluate methods for communicative and systemic learning, effective functioning in a critical learning system, and participation in co-management. We conclude that agroecology provides the framework and the methods for effective systems education, based on transdisciplinary research, which can shape our future learning landscapes and develop compentencies needed for responsible action by agroecologists.

\section{REFERENCES}

Altieri, M. A. 1983. Agroecology. Univ. California Press, Berkeley, California.

Altieri, M. A., and Francis, C. A. 1992. Incorporating agroecology into the conventional agricultural curriculum. Amer. J. Altern. Agric. 7: 89-93.

American Society of Agronomy. 2006. Case Studies Published in Journal of Natural Resources and Life Sciences Education, 1992-2005. Amer. Soc. Agron., Madison, Wisconsin.

Barnett, R. (Ed.). 2005. Reshaping the University: New Relationships Between Research, Scholarship, and Teaching. McGraw Hill/Open Univ. Press, Maidenhead, U.K.

Basarab, N. 2002. Manifesto of Transdisciplinarity. State Univ. New York Press, Albany, New York.

Batie, S. 2008. Sustainability science: Statement of the Friiberg workshop on sustainability Science. Amer. J. Agri. Econ. 90: 1176-1191.

Bawden, R. J. 1991. Systems thinking and practice in agriculture. J. Dairy Sci. 74: 2362-2373.

Bawden, R. J. 2005. Systemic development at Hawkesbury: Some personal lessons from experience. Sys. Res. Behav. Sci. 22: 151-164.

Bawden, R. J. 2007a. Knowing systems and the environment. In: Sage Handbook on Environment and Society. pp. 224-234. Pretty, J., Ball, A., Benton, T., Guivant, J., Lee, D. R., Orr, D., Pfeffer, M. andWard, H., Eds. Sage Publ., London.

Bawden, R. J. 2007b. Pedagogies for persistence: Cognitive challenges and collective competencies. Intl. J. Sustain. Devel. Innovation 2: 299-314.

Berkes, F. 2007. Understanding uncertainty and reducing vulnerability: Lessons from resilience thinking. Natural Hazards 41: 283-295. 
Boody, G., Vondracek, B., Andow, D. A., Krinke, M., Westra, J., Zimmerman, J., and Welle, P. 2005. Multifunctional agriculture in the United States. Bioscience 55: 27-38.

Brew, A., and Baud, D. 1995.Teaching and research: establishing the vital link with learning. Higher Educ. 29: 261273.

Caporali, F., Lieblein, G., von Fragstein, P., and Francis, C. (Eds.). 2007. Teaching and Research in Agroecology and Organic Farming: Challenges and Perspectives. Proceedings European Network of Organic Agriculture Teachers (ENOAT). Pieve Tesino (TN), Italy, Aug. 29-Sep. 2.

Carpenter, S. R., Mooney, H. A., Agard, J., Capistrano, D., DeFries, R. S., Diaz, S., Dietz, T., Duraiappah, A. K., Oteng-Yeboah, A., Pereira, H. M., Perrings, C., Reid, W. V., Sarukhan, J., Scholes, R. J., and Whyte, A. 2009. Science for managing ecosystem services: Beyond the Millennium Ecosystem Assessment. Proc. Nat. Acad. Sci. 106: 1305-1312.

Checkland, P. B. 1981. Systems Thinking, Systems Practice. John Wiley, New York.

Checkland, P. B., and Scholes, J. 1990. Soft Systems Methodology in Action. John Wiley, Chichester, U.K.

Clark, W. C. 2006. Sustainability science: A room of its own. Proc. Nat. Acad. Sci. 104: 1737-1738.

Cook, W. M., Casagrande, D. G., Hope, D., Groffman, P. M., and Collins, S. L. 2004. Learning to roll with the punches: Adaptive experimentation in human-dominated systems. Frontiers Ecol. Environ. 2: 467-474.

Cottingham, K. L. 2002. Tackling biocomplexity: The role of people, tools, and scale. Bioscience 52: $793-799$.

Daily, G. C. (Ed.). 1997. Nature's Services: Societal Dependence on Natural Ecosystems. Island Press, Washington, D.C.

Dalgaard, T., Hutchings, N. J., and Porter, J. R. 2003. Agroecology, scaling and interdisciplinarity. Agric. Ecosys. \& Environ. 100: 39-51.

Dewey, J. 1916. Democracy and Education: An Introduction to The Philosophy of Education, 1966 Edition. Free Press, New York.

Doering, A. 2006. Adventure learning: Transformative hybrid online education. Distance Education 27: $197-215$.

Eaglesham, A. 2006. Summary Proceedings: Third Annual World Congress on Industrial Biotechnology and Bioprocessing. 11-14 July 2006, Toronto, Canada. nabc.cals.cornell.edu/pubs/WCIBB2006 proc.pdf. Accessed on 23 June 2009.

Flora, C.B. 2001. Shifting agroecosystems and communities, In: Interactions Between Agroecosystems and Rural Communities. pp. 5-14. Flora, C.B. Ed., CRC Press, Boca Raton, Florida.

Francis, C. A. 2009. Education in organic farming and food systems. In: Organic Farming: The Ecological System. pp. 283-300.

Francis, C. A., Ed., Agron. Monograph 54, Amer. Soc. Agron., Madison, Wisconsin.

Francis, C., King, J., Lieblein, G., Breland, T. A., Salomonsson, L., Sriskandarajah, N., Porter, P., andWiedenhoeft, M. 2009. Open-ended cases in agroecology: Farming and food systems in the Nordic Region and the U.S. Midwest. J. Agric. Educ. \& Extension 15: 385-400.

Francis, C., Lieblein, G., Breland, T. A., Salomonsson, L., Geber, U., Sriskandarajah, N., and Langer, V. 2008. Transdisciplinary research for a sustainable agriculture and food sector. Agron. J. 100: 771-776. 
Francis, C., Lieblein, G., Gliessman, S., Breland, T. A., Creamer, N., Harwood, R., Salomonsson, L., Helenius, J., Rickerl, D., Salvador, R., Wiedenhoeft, M., Simmons, S., Allen, P., Altieri, M., Flora, C. and Poincelot, R. 2003. Agroecology: The ecology of food systems. J. Sustain. Agric. 22: 99-118.

Francis, C. A., and Porter, P. 2010. Ecology in sustainable agriculture practices and systems. CRC Crit. Rev. Plant Sci. (this issue)

Freire, P. 1970. Pedagogy of the Oppressed. Translated by Myra Bergman Ramos. Seabury Press, New York. Gliessman, S. R. 1984. An agroecological approach to sustainable agriculture. In: Meeting the Expectations of the Land. pp. 160-171. Jackson, W., Berry, W., and Colman, B. Eds., Northpoint Press, Berkeley, California.

Gliessman, S. R. 2007. Agroecology: The Ecology of Sustainable Food Systems. CRC Press, Taylor and Francis, New York.

Harms, K., King, J., and Francis, C. 2009. Behavioral changes based on a course in agroecology: A mixed methods study. J. Nat. Res. Life Sci. Educ. 38: 183-194.

Hattie, J., and Marsh, H.W. 1996. The relationship between research and teaching: A meta-analysis. Rev Educ. Res. 66: $507-542$.

Hattie, J., and Marsh, H. W. 2002. The relation between research productivity and teaching effectiveness. J. Higher Educ. 73: 603-641.

Hendrickson, C. T., Lve, L. B., and Matthews, H. S. 2006. Environmental Life Cycle Assessment of Goods and Services: An Input-Output Approach. Resources for the Future Press, Washington, DC.

Ison, R., Maiteny, P., and Carr, S. 1997. Systems methodologies for sustainable natural resources research and development. Agric. Systems 55: 257-272.

Ison, R., Roling, N., andWatson, D. 2007. Challenges to science and society in the sustainable management and use of water: Investigating the role of social learning. Environ. Sci. Policy 10: 499-511.

Jenkins, A., Breen, R., and Lindsay, R. 2003. Reshaping Teaching in Higher Education: Linking Teaching with Research. Routledge Ltd., New York.

Jordan, N., Andow, D. A., and Mercer, K. L. 2005. Newconcepts in agroecology: A service-learning course. J. Nat. Resources \& Life Sci. Educ. 34: 83-89.

Jordan, N, Bawden, R., and Bergmann, L. 2008 Sustainability and epistemic competencies: Facing the 'worldview challenge' in sustainable development of agriculture. J. Natural Res. \& Life Sci. Educ. 37: 92-99.

Jordan, N., Boody, G., Broussard, W., Glover, J. D., Keeney, D., McCown, B. H., McIsaac, G., Muller, M., Murray, H., Neal, J., Pansing, C., Turner, R. E., Warner, K., and Wyse, D. 2007. Sustainable development of the agricultural bio-economy. Science 316: 1570-1571.

Kallis, G., Videira, N., Antunes, P., Pereira, A. G., Spash, C. L., Coccossis, H., Quintana, S. C., Del Moral, L., Hatzilacou, D., Lobo, G., Mexa, A., Paneque, P., Matcos, B., and Santos, R. 2006. Participatory methods forwater resources planning. Environ. Planning C-Government and Policy 24: 215-234.

Kirschenmann, F. 2009. Farming in the middle: An ethical imperative. In: Organic Farming: The Ecological System. pp. 325-342. Francis, C.A. Ed., Agron. Monograph 54, Amer. Soc. Agron., Madison, Wisconsin.

Kolb, D. 1984. Experiential Learning: Experience as the Source of Learning and Development. Prentice-Hall, Inc., Upper Saddle River, New Jersey. 
Lieblein, G., Breland, T. A., Østergaard, E., Salomonsson, L., and Francis, C. 2007. Educational perspectives in agroecology: Steps on a dual learning ladder toward responsible action. NACTA J. 51: 37-44.

Lieblein, G., and Francis, C. 2007a. Integration of teaching and research. Proceedings European Network of Organic Agriculture Teachers (ENOAT). pp. 28-43. Caporali, F., Lieblein, G., von Fragstein, P., and Francis, C. Eds., Pieve Tesino (TN), Italy, Aug. 29-Sept. 2.

Lieblein, G., and Francis, C. 2007b.. Towards responsible action through agroecological education. Italian J. Agronomy/Riv. Agron. 2: 79-86.

Lieblein, G., Francis, C., Barth-Eide, W., Torjusen, H., Solberg, S., Salomonsson, L., Lund, V., Ekblad, G., Persson, P., Helenius, J., Loiva, M., Sep“annen, L., Kahiluoto, H., Porter, J., Olsen, H., Sriskandarajah, N., Mikk, M., and Flora, C. 2000a. Future education in ecological agriculture and food systems: a student-faculty evaluation and planning process. J. Sustain. Agric. 16: 49-69.

Lieblein, G., Francis, C., and King, J. 2000b. Conceptual framework for structuring future agricultural colleges and universities. J. Agric. Educ. Extension (Wageningen) 6: 213-222.

Lieblein, G., Francis, C., Salomonsson, L., and Sriskandarajah, N. 1999. Ecological agriculture research: Increasing competence through PhD courses. J. Agric. Education and Extension 6: 31-46.

Lieblein, G., Moulton, M., Waalen, W., Breland, T. A., Francis, C., Sriskandarajah, N., Porter, J., Helenius, J., Salomonsson, L., and Langer, V. 2005. Systems thinking and experiential learning: a Nordic net-based course in agroecology: Integrating student learning and teacher collaboration. European Journal of Open and Distance Learning [EURODL] Vol. 1. [http://eurodl.org/materials/contrib./2005/Lieblein.htm].

Lieblein, G., Østergaard, E., and Francis, C. 2004. Becoming an agroecologist through action education. Intl. J. Agric. Sustainability 2: 1-7.

Liu, J. G., Dietz, T., Carpenter, S. R., Folke, C., Alberti, M., Redman, C. L., Schneider, S. H., Ostrom, E., Pell, A. N., Lubchenco, J., Taylor, W. W., Ouyang, Z. Y., Deadman, P., Kratz, T., and Provencher, W. 2007. Coupled human and natural systems. Ambio 36: 639-649.

Mandarano, L. A. 2008. Evaluating collaborative environmental planning outputs and outcomes: restoring and protecting habitat and the New York New Jersey Harbor Estuary Program. J. Planning Educ. Res. 27: 456-468.

Margerum, R. D. 2002. Evaluating collaborative planning: Implications from an empirical analysis of growth management. J. Amer. Planning Assoc. 68: 179-193.

Mezirow, J. 1996. Contemporary paradigms of learning. Adult Educ. Quart. 46: 158-172.

Mittelstrass, J. 1998. Die H"auser des Wissens. Wissenschaftstheoretische Studien. Frankfurt/Main, pp. 29-48.

Olsson, P., Folke, C., Galaz, V., Hahn, T., and Schultz, L. 2007. Enhancing the fit through adaptive co-management: Creating and maintaining bridging functions for matching scales in the Kristianstads Vattenrike Biosphere Reserve, Sweden. Ecol. Soc. 12: Art. No. 28.

Pahl-Wostl, C., and Hare, M. 2004. Process of social learning in integrated resources management. J. Commun. Appl. Psychol. 14: 193-206.

Palmer, S., Nilsson, A., andRoigart, A. 2008. Dynamic change in rice production systems in the Mekong Delta: a students field study report from An Gian. Rapporter Institutionen f' or Stad och Land, number 3/2008. Swedish Univ. Agric. Sci., Uppsala, Sweden.

Peters C., Bills N., Lembo A.,Wilkins, J., and Fick, G. 2009. Mapping potential foodsheds in New York State: A spatial model for evaluating the capacity to localize food production. Renew. Agric. Food Syst. 24: 72-84. 
Pickett S., Cadenasso, M., and Grove, J. 2005. Biocomplexity in coupled natural-human systems: A multidimensional framework. Ecosystems 8: 225-232.

Pogranichniy, S., Burras, L., Polito, T. A., andWiedenhoeft, M. H. 2001. Freshman learning communities in agriculture: Observations and assessment. J. Nat. Res. Life Sci. Educ. 30: 104-110.

Pretty, J. 1995. Participatory learning for sustainable agriculture. World Devel. 23(8): 1247-1263.

Rickerl, D., and Francis, C. (Eds.). 2004. Agroecosystems analysis. Monograph Series No. 43, Amer. Soc. Agron., Madison, Wisconsin.

Robertson, G. P., Allen,V. G., Boody, G., Boose, E. R., Creamer, N. G., Drinkwater, L. E., Gosz, J. R., Lynch, L., Havlin, J. L., Jackson, L. E., Pickett, S. T. A., Pitelka, L., Randall, A., Reed, A. S., Seastedt, T. R., Waide, R. B., and Wall, D. H. 2008. Long-term agricultural research: A research, education, and extension imperative. Bioscience 58: $640-645$.

Salner, M. 1986. Adult cognitive and epistemological development in systems education. Syst. Res. 3: 225 232.

Salomonsson, L., Francis, C., Lieblein, G., and Furugren, B. 2005. Just in time education. NACTA J. December 49: $5-13$.

Salomonsson, L., Nilsson, A., Palmer, S., Roigart, A., and Francis, C. 2008. Farming systems education: Case study of Swedish test pilots. Renewable Agric. Food Systems 24: 48-59.

Samson, F., and Knopf, F. 1994. Prairie conservation in North America. Bioscience 44: 418-421.

Schunn, C. D., Crowley, K., and Okada, T. 1998. The growth of multidisciplinarity in the cognitive science society. Cognitive Sci. 22: 107-130.

Sriskandarajah, N., Bawden, R. J., and Packham, R. G. 1990. Systems agriculture: A paradigm for sustainability. AFSRE Newsletter 2: 1-5.

Steyaert, P., Barzman M., Billaud J. P., Brives, H., Hubert, B., Ollivier, G., and Roche, B. 2007. The role of knowledge and research in facilitating social learning among stakeholders in natural resources management in the French Atlantic coastal wetlands. Environ. Sci. Policy 10: 537-550.

Tonn, B., English, M., and Travis, C. 2000. A framework for understanding and improving environmental decision making. J. Environ. Planning Management 43: 163-183.

Uphoff, N. (Ed.). 2002. Agroecological Innovations: Increasing Food Production with Participatory Development. Earthscan Publ., Sterling, Virginia.

Warner, K. D. 2008. Agroecology in Action Extending Alternative Agriculture Through Social Networks. MIT Press, Cambridge, Massachusetts.

Wezel, A., Bellon, S. Dore, T., Francis, C., Vallod, D., and David, C. 2009 Agroecology as a science, a movement or a practice. Agron. Sustain. Devel. (DOI: 10.1051/agro/200904). Available online at: www.agronomy-journal.org Accessed 21 September 2009.

Wiedenhoeft, M., and Loynachan, T. 2009. Student-centered learning experiences at Iowa State University. Agron. Abstr., 2009.54968, Amer. Soc. Agron., Madison, Wisconsin. http://acs.confex.com/crops/2009am /webprogram/Paper54968.html, Accessed 24 January 2010. 
Wiedenhoeft, M., Simmons, S., Salvador, R., McAndrews, G., Francis, C., King, J., and Hole, D. 2003.

Agroecosystems analysis from the grass roots: A multidimensional experiential learning course. J. Natural Res. Life Sci. Educ. 32: 73-79.

Wilson, K., and Morren Jr., G. E. B. 1990. Systems Approaches for Improvement in Agriculture and Resource Management. Macmillan Publ., New York. 